\title{
Insertion Area in the Mandible Masticatory Muscles for use in Finite Element Analyses
}

\author{
Área de Inserción en la Mandíbula de los Músculos de Masticación \\ para ser Utilizados en Análisis por Elementos Finitos
}

Eduardo Borie ${ }^{* * * *}$; Iara Augusta Orsi“*; Gonzalo Muñoz ${ }^{* * * *}$; Luiz Gustavo de Souza ${ }^{* * * * *}$ \& Mariano del Sol ${ }^{* * * * *, * * * * * * * *}$

BORIE, E.; ORSI. I. A.; MUÑOZ, G.; DE SOUZA, L. G. \& DEL SOL, M. Insertion area in the mandible masticatory muscles for use in finite element analyses. Int. J. Morphol., 33(4):1377-1379, 2015.

SUMMARY: To validate the virtual finite element analysis (FEA) results, it is needed that the mathematical models take into account the insertion area. Thus, the aim of this study was to measure the insertion area of masticatory muscles in the mandible in human cadavers to be used in FEA. The insertion area of the masticatory mandible's muscles was measured on both sides of fifty human cadavers throughout digital photos and software. The insertion area of the masseter was $7.47( \pm 0.41) \mathrm{cm}^{2}$, the temporal (inner portion) was $3.05( \pm 0.13) \mathrm{cm}^{2}$, the temporal (outer portion) was $2.25( \pm 0.28) \mathrm{cm}^{2}$, the medial pterygoid was $2.2( \pm 0.23) \mathrm{cm}^{2}$, and the lateral pterygoid was $0.8( \pm 0.05) \mathrm{cm}^{2}$. In conclusion, there is enough data to be used for the finite element analysis.

KEY WORDS: Masticatory muscles; Insertion area; Finite element analysis.

\section{INTRODUCTION}

The finite element analysis (FEA) is widely used in the medical and dental field to study the biomechanical behavior of systems and/or structures with complex geometries. The results of these simulations may provide information that clinically is not yet available, reducing the time and repetitive clinical experiences (Tang et al. 2012). However, in certain conditions, due to the great complexity of the systems, there is a need for simplification, which should not interfere with the results of the FEA. Factors that must be considered and that may influence in the accuracy of the analysis are the correct geometry of the structures or systems to be modeled, material properties, boundary conditions, interface between the adjacent surfaces, and loads (Geng et al., 2001).

In all studies analyzed through the finite element, involving the mandible is required to include the masticatory muscles, with an accurate modeling of muscle actions (Daas et al., 2008). That is because the mandible is a dynamic structure, and the masticatory muscles are responsible for controlling the mandibular position and generate an adequate amount of loads during the function (Nomura et al., 2003).
To validate the virtual FEA results, the mathematical models should take into account the insertion area of the muscles involved and the respective direction of the force vectors. The literature reports the loads values, equations, and vectors simulating the action of the masticatory muscles at the mandible. However, there is a lack of information about the distribution of the insertion area in the mandible of the masticatory muscles. Thus, the aim of this study was to measure the insertion area of the masticatory muscles in the mandible in human cadavers to be used in the finite element analysis.

\section{MATERIAL AND METHOD}

The insertion area of the masticatory mandible's muscles was measured on both sides of fifty human cadavers through digital photos together with a calibrated ruler on the same plane of the surface to be analyzed (Fig. 1). Later, these photographs were analyzed using the Image J version

\footnotetext{
Research Centre in Dental Sciences (CICO), Dental School, Universidad de La Frontera, Temuco, Chile.

** Dental Materials and Prosthodontics Department, Ribeirão Preto Dental School, University of São Paulo, Ribeirão Preto, Brazil.

*** Student of Dental School, Universidad de la Frontera, Temuco, Chile.

**** Morphology, Stomatology and Physiology Department, Ribeirão Preto Dental School, University of São Paulo, Ribeirão Preto, Brazil.

****** Basic Sciences Department, Faculty of Medicine, Universidad de La Frontera, Temuco, Chile.

******* Center for Biomedical Research, Universidad Autónoma de Chile, Temuco, Chile.
} 
BORIE, E.; ORSI. I. A.; MUÑOZ, G.; DE SOUZA, L. G. \& DEL SOL, M. Insertion area in the mandible masticatory muscles for use in finite element analyses. Int. J. Morphol., 33(4):1377-1379, 2015.

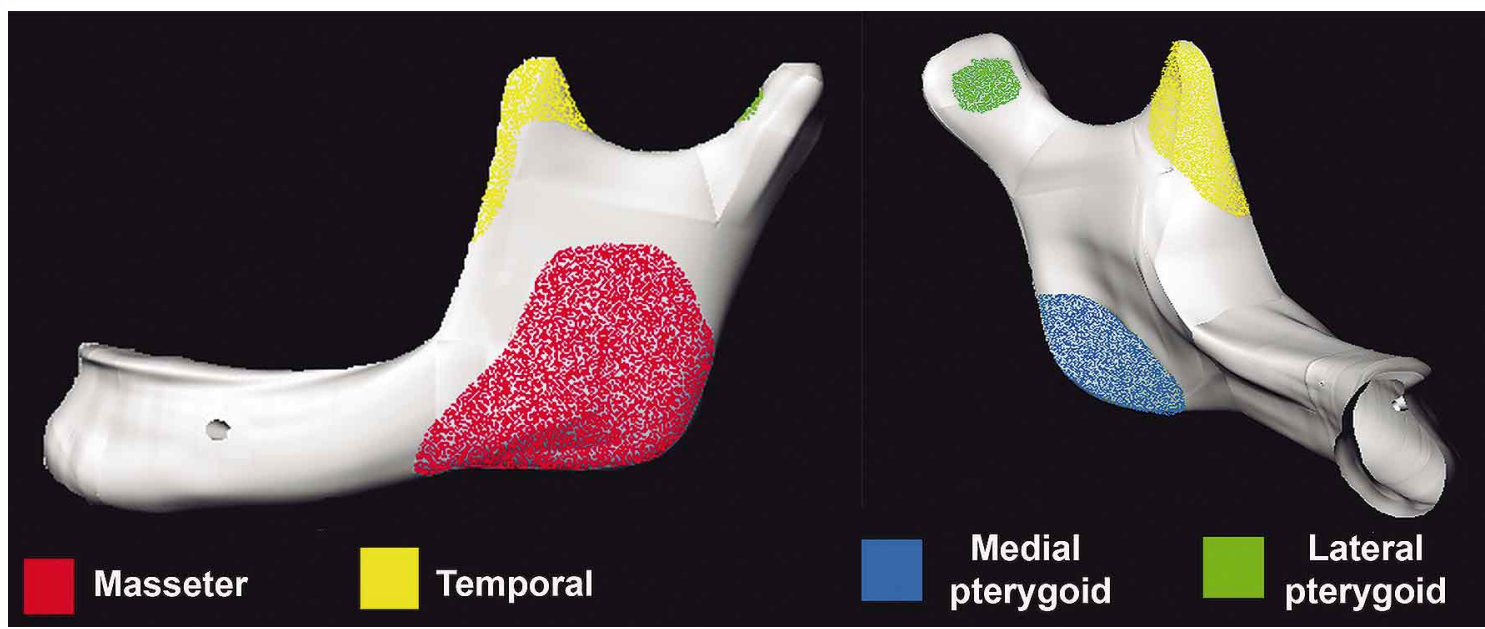

Fig. 1. Insertion of the masticatory muscles at the mandible from lateral and medial views.

1.47k (http://rsbweb.nih.gov/ij/) to obtain the total area of each sample.

Some muscles were discarded, mainly, by the lack or damage on both their bone and muscle structure, obtaining a dissimilar final sample for each masticatory muscle: being masseter $(n=89)$, temporal - inner portion $(n=38)$ and outer portion $(n=86)$, medial pterygoid $(n=62)$, and lateral pterygoid $(n=48)$.

Data were recorded in an Excel table and subsequently analyzed using the Shapiro-Wilk test in the SPSS software (v.15.0, SPSS Inc., Chicago, IL, USA) to determine the normal distribution. Once the test was performed, the mean and standard deviation were recorded in the Table I.

\section{RESULTS AND DISCUSSION}

The strength analysis for any mandibular movement requires the establishment of contribution of each muscle involved. Considering that muscles are the determinants in the mandibular movements, it is important to know their

Table I. Mean and standard deviation of the insertion area of the masticatory mandible's muscles in humans.

\begin{tabular}{lccc}
\hline Muscle & n & Mean (cm2) & SD \\
\hline Masseter & 89 & 7.47 & 0.41 \\
Temporal (inner portion) & 38 & 3.05 & 0.13 \\
Temporal (outer portion) & 86 & 2.25 & 0.28 \\
Medial pterygoid & 62 & 2.2 & 0.23 \\
Lateral pterygoid & 48 & 0.8 & 0.05 \\
\hline
\end{tabular}

insertion areas in the mandible to carry out finite element studies as real as possible. The insertion areas of masseter, temporal, medial, and lateral pterygoid muscles were assessed because these are the main muscles that control the mandibular movements during the mastication act.

In the FEA of the musculoskeletal system, the insertion area of the muscles involved in the mastication process, as well as the values and vector directions of the muscle loads (Commisso et al., 2015), must be considered. Some researches (Koolstra et al., 1988; Koolstra \& van Eijden, 1992; Gröning et al., 2012) used the cross-sectional area of each muscle. However, this area does not correspond to the real insertion area of the masticatory muscles at the mandible.

The mean and standard deviation of the insertion area of each masticatory mandible's muscle is summarized in Table 1. The masseter muscle showed the highest insertion area, followed by the temporal muscle. These results are according to the report by Guimarães et al. (2013), which observed the highest number of fibers inserted in the mandible's ramus and body, and coronoid process, respectively, for the same muscles.

In the finite element studies, the loads shall be established as external loads and distributed on the model surface areas that correspond to the areas where each muscle is attached (Gröning et al.; Commisso et al.). These areas can be obtained from dissections, computed tomography, magnetic resonance by the connection between the origin, and insertion of each masticatory muscle in dry skulls (Gröning et al.). Changes in the insertion areas of each muscle may cause alterations of the muscle loads and, consequently, affecting the final results obtained through the FEA (Gröning et al.). 
A research by Barbarino et al. (2009) described an anatomically detailed finite element model of the face, which includes the masticatory muscles reconstructed from the magnetic resonance. However, they do not report quantitatively any information about the distribution of the insertion area in the mandible of the masticatory muscles. This information may be valuable in performing a FEA due to the intensity of the force that depends on the area of the surface over which the force is distributed.

One limitation of this study was the impossibility to separately measure the insertion area of the deeper and super- ficial portion of the masseter muscle, as well as the temporal muscle insertion as a unique muscle, without separating it as inner and outer portions. However, there is enough data to be used for in silico assays, as an example, finite element analysis.

\section{ACKNOWLEDGMENT}

The authors want to acknowledge Mr. Julio Guajardo (Universidad de La Frontera, Chile) by the help provided in this study.

BORIE, E.; ORSI. I. A.; MUÑOZ, G.; DE SOUZA, L. G. \& DEL SOL, M. Área de inserción en la mandíbula de los músculos de masticación para ser utilizados en análisis por elementos finitos. Int. J. Morphol., 33(4):1377-1379, 2015.

RESUMEN: Para validar los resultados virtuales de análisis por elementos finitos (FEA) es necesario que los modelos matemáticos consideren el área de inserción muscular. Así, el objetivo de este estudio fue medir el área de inserción en la mandíbula de los músculos de masticación en cadáveres humanos para ser utilizado en FEA. El área de inserción en la mandíbula de los músculos de masticación fue medida en ambos lados de cincuenta cadáveres humanos por medio de fotografías digitales y software. El área de inserción del músculo masetero fue $7,47( \pm 0,41) \mathrm{cm}^{2}$, la porción interna del músculo temporal fue de $3,05( \pm 0,13) \mathrm{cm}^{2}$ y su porción externa de $2,25( \pm 0,28) \mathrm{cm}^{2}$, para los músculos pterigoideo medial fue de $2,2( \pm 0,23) \mathrm{cm}^{2}$ y pterigoideo lateral $0,8( \pm 0,05) \mathrm{cm}^{2}$. En conclusión, los datos son suficientes para ser utilizados para análisis de elementos finitos.

PALABRAS CLAVE: Músculos de masticación; Área de inserción; Análisis por elementos finitos.

\section{REFERENCES}

Barbarino, G. G.; Jabareen, M.; Trzewik, J.; Nkengne, A.; Stamatas, G. \& Mazza, E. Development and validation of a three-dimensional finite element model of the face. J. Biomech. Eng., 131(4):041006, 2009.

Commisso, M. S.; Martínez-Reina, J.; Ojeda, J. \& Mayo, J. Finite element analysis of the human mastication cycle. J. Mech. Behav. Biomed. Mater., 41:23-35, 2015.

Daas, M.; Dubois, G.; Bonnet, A. S.; Lipinski, P. \& Rignon-Bret, C. A complete finite element model of a mandibular implantretained overdenture with two implants: comparison between rigid and resilient attachment configurations. Med. Eng. Phys., 30(2):218-25, 2008.

Geng, J. P.; Xu, D. W.; Tan, K. B. \& Liu, G. R. Finite element analysis of an osseointegrated stepped screw dental implant. J. Oral Implantol., 30(4):223-33, 2004.

Gröning, F.; Fagan, M. \& O'Higgins, P. Modeling the human mandible under masticatory loads: which input variables are important? Anat. Rec. (Hoboken), 295(5):853-63, 2012.

Guimarães, T. B.; Ferreira, M. B.; Wakamatsu, A.; Oliveira, S. R.; Guimarães, A. S.; Suazo G., I. \& Marie, S. N. Muscle fiber type composition, fiber diameter, capillary density in temporalis and masseter muscles and correlation with bite force. Int. J. Morphol., 31(2):747-53, 2013.
Koolstra, J. H.; van Eijden, T. M.; Weijs, W. A. \& Naeije, N. A threedimensional mathematical model of the human masticatory system predicting maximum possible bite forces. J. Biomech., 21(7):563-76, 1988.

Koolstra, J. H. \& van Eijden, T. M. Application and validation of a three-dimensional mathematical model of the human masticatory system in vivo. J. Biomech., 25(2):175-87, 1992.

Nomura, T.; Gold, E.; Powers, M. P.; Shingaki, S. \& Katz, J. L. Micromechanics/structure relationships in the human mandible. Dent. Mater., 19(3):167-73, 2003.

Tang, C. B.; Liul, S. Y.; Zhou, G. X.; Yu, J. H.; Zhang, G. D.; Bao, Y. D. \& Wang, Q. J. Nonlinear finite element analysis of three implantabutment interface designs. Int. J. Oral Sci., 15(4):101-8, 2012.

\section{Correspondence to:}

Eduardo Borie Echevarría

Dental School

Universidad de La Frontera

Av. Francisco Salazar 01145

Temuco

CHILE

Received: 26-07-2015

Accepted: 16-09-2015

Email: eduardo.borie@ufrontera.cl 